\title{
Analisis Proksimat Tepung Jonjot Buah Labu Kuning
}

\section{Dokri Gumolung ${ }^{* a}$,Meiske Naomi Mamuaja ${ }^{a}$}

a Kimia, FMIPA, Universitas Negeri Manado, Tondano, 95618, Indonesia

\begin{tabular}{l} 
IN F O A R T I K E L \\
\hline Diterima 7 Agustus 2018 \\
Disetujui 21 Agustus 2018 \\
\hline Key word: \\
Yellow Pumpkin Strands \\
Proximate \\
\\
\hline Kata kunci: \\
Jonjot Labu Kuning, \\
Proksimat
\end{tabular}

\footnotetext{
*e-mail:

dokrigumolung@unima.ac.id

*Telp:

085396672121
}

\begin{abstract}
A BSTRACT
The purpose of this study was to measure the levels of protein, fat, fiber, carbohydrates, water and ash, in jumpy flour from pumpkin. Pumpkin strands are part of the pumpkin fruit where the pumpkin seeds are attached to the inside of the fruit flesh. In processing pumpkin as a food, strands often used as waste or waste and is considered as a fruit that is not useful. Pumpkin plants as a minor food commodity, it turns out, are very rich in bioactive compounds which act as anti-oxidants which are very useful for human health, including spikes that have not been maximized until now due to the lack of scientific information on nutrient content and bioactive compounds in pumpkin fruit jots. This research was carried out using laboratory analysis methods with the following stages, determination and sampling, sample preparation, protein content analysis of the gunning method, fat content, fiber content, carbohydrate content and water and ash content by oven drying method. The results of the study showed that jumpy flour from pumpkin had protein content of $1.09 \%$, fat of $5.15 \%$, fiber of $1.27 \%$, carbohydrate of $73.38 \%$, water of $14.68 \%$ and ash of $4.45 \%$. The results of this study concluded that pumpkin fruit pumpkin flour can be used as food fortification material to increase nutritional value.
\end{abstract}

\section{A B S T RAK}

Tujuan penelitian ini adalah untuk mengukur kadar protein, lemak, serat, karbohidrat, air dan abu, pada tepung jonjot dari buah labu kuning. Jonjot labu kuning adalah bagian dalam dari buah labu kuning tempat dimana biji buah labu kuning melekat dan menyatu dengan bagian dalam daging buah. Dalam pengolahan buah labu kuning sebagai bahan pangan, jonjot sering dijadikan limbah atau buangan dan dianggap sebagai bagian buah yang tidak bermanfaat. Tanaman labu sebagai komoditas pangan minor, ternyata sangat kaya dengan senyawa bioaktif yang berperan sebagai antiokisidan yang sangat berguna bagi kesehatan manusia, termasuk jonjot yang sampai saat ini pemanfaatannya belum dimaksimalkan dikarenakan minimnya informasi ilmiah dari kandungan zat gizi dan senyawa bioaktifdidalam jonjot buah labu kuning. Penelitian ini dilaksanakan dengan menggunakan metode analisis laboratorium dengan tahapan-tahapan sebagai berikut, penentuan dan pengambilan sampel, preparasi sampel, analisis kadar protein metode gunning, kadar lemak, kadar serat, kadar karbohidrat dan kadar air dan abu dengan metode oven pengeringan. Hasil penelitian menunjukkan bahwa tepung jonjot dari buah labu kuning memiliki kadar protein 1,09\%, lemak 5,15\%, serat 1,27\%, karbohidrat 73,38 $\%$, air 14,68 \% dan Abu 4,45\%. Hasil penelitian dapat disimpulkan bahwa tepung jonjot buah labu kuning dapat dijadikan sebagai bahan fortifikasi pangan untuk meningkatkan nilai gizi.

\section{Pendahuluan}

Labu kuning atau waluh (Cucurbita moschata), termasuk dalam komoditas pangan yang pemanfaatannya masih sangat terbatas. Banyak bahan pangan lokal Indonesia yang mempunyai potensi gizi dan komponen bioaktif yang baik, namun belum termanfaatkan secara optimum [1]. Tanaman labu kuning sebagai komoditas pangan minor, ternyata sangat kaya dengan senyawa bioaktif yang sangat berguna bagi kesehatan manusia, namun penelitian tentang karakterisasi dan potensi pemanfaatan komoditas pangan minor masih sangat sedikit dibandingkan komoditas pangan utama, seperti padi dan kedelai. Labu kuning merupakan bahan pangan yang kaya vitamin A dan C, mineral, serta karbohidrat. Daging buah mengandung antiokisidan dan juga antifotooksidasi sebagai penangkal pelbagai jenis kanker. Buah labu kuning dapat digunakan untuk pelbagai jenis makanan, daunnya berfungsi sebagai sayur, air buahnya berguna sebagai penawar racun binatang berbisa, sementara bijinya menjadi obat cacing pita, namun sejauh ini pemanfaatannya belum optimal [2]. Melihat kandungan gizinya, olahan dari labu kuning sangat baik dikonsumsi oleh anak-anak maupun orang tua. Lewat sejumlah 
penelitian yang dilakukan para ahli diketahui pula, labu kuning memainkan peranan penting dalam mencegah penyakit degeneratif seperti diabetes mellitus (kencing manis), arterosklerosis (penyempitan pembuluh darah), jantung koroner, tekanan darah tinggi, bahkan bisa pula mencegah kanker. Jonjot labu kuning memiliki potensi yang sangat besar sebagai sumber senyawa yang berperan sebagai antioksidan alami seperti senyawa beta karoten dan fenolik, namun belum banyak data yang tersedia untuk menggali potensi antioksidan, bahkan jonjot dalam pengolahan bahan makanan dari labuh kuning sering dijadikan limbah [3, 4].

\section{Bahan dan Metode}

Bahan utama yang digunakan dalam penelitian ini adalah buah labu kuning umur panen 3-4 bulan, yang diperoleh dari Daerah Modoinding Minahasa Selatan Propinsi Sulawesi Utara. Bagian buah yang digunakan untuk penelitian ini adalah kulit, daging, jonjot, dan biji. Bahan kimia yang digunakan adalah petroleum eter, etanol, natrium hidroksida, asam sulfat, natrium karbonat. Alat-alat oven pengeringan, tanur, soklet.

\section{Preparasi Sampel}

Buah labu kuning dibersihkan/dicuci dengan air, selanjutnya dipisahkan bagian kulit, daging, biji dan jonjot. Bagian jonjot buah yang sudah dipisahkan kemudian dikeringkan dengan oven pada suhu $60-70{ }^{\circ} \mathrm{C}$, setelah kering dihaluskan dengan menggunakan blender, selanjutnya diayak sampai diperoleh partikel dengan ukuran 60 mesh dan diperoleh tepung jonjot buah labu kuning.

\section{Analisis proksimat}

Tepung jonjot dianalisis kadar protein dengan metode gunning, kadar lemak dengan metode Soxhlet [5], kadar serat dan karbohidrat dianalisis sesuai dengan SNI 01-2891-1992 [6], dan kadar air dengan metode oven pengeringan dan kadar abu dengan metode tanur pembakar.

\section{Hasil dan Pembahasan}

Hasil Analisis Proksimat

Tepung jonjot labu kuning yang diperoleh, telah dilakukan pengukuran kandungan gizi, dan hasil analisis dapat dilihat pada Tabel 1 di bawah ini.

Tabel 1. Analisis Proksimat Tepung Jonjot Buah Labu Kuning

\begin{tabular}{|l|c|}
\hline \multicolumn{1}{|c|}{ Zat Gizi } & Kadar (\%) \\
\hline Protein & 1,09 \\
Lemak & 5,15 \\
Serat & 1,27 \\
Karbohidrat & 73,38 \\
Kadar Air & 14,68 \\
Kadar Abu & 4,45 \\
\hline
\end{tabular}

\section{Protein}

Kadar protein diperoleh dari tepung jonjot buah labu kuning yaitu 1,09\% dibandingkan dengan data yang diungkapkan oleh Kamsiati (2010), dimana kadar protein tepung labu kuning sebesar 3,74\% [7]. Hal ini dapat disimpulkan bahwa kandungan protein pada jonjot, buah labu kuning dalam penelitian ini lebih rendah kandungannya dibandingkan dengan penelitian sebelumnya.

Protein merupakan suatu zat makanan yang amat penting bagi tubuh, karena zat ini berfungsi sebagai zat pembangun dan pengatur. Sebagai zat pembangun protein merupakan bahan pembentuk jaringanjaringan baru yang selalu terjadi dalam tubuh. Semakin tinggi kadar protein pada bahan makanan tersebut maka kualitas bahan makanan tersebut akan semakin bagus nilai gizinya bagi manusia. Fungsi utama protein bagi tubuh ialah untuk membentuk jaringan baru dan mempertahankan jaringan yang telah ada. Protein dapat juga di gunakan untuk bahan bakar apabila keperluan energi tunbuh tidak terpenuhi oleh karbohidrat dan lemak. Protein mengatur keseimbangan cairan dalam jaringan dan pembuluh darah, yaitu dengan menimbulkan tekanan osmotic koloid yang dapat menarik cairan dari jaringan ke dalam pembuluh darah. Sifat atmosfer protein yang dapat bereaksi dengan asam dan basa, dapat mengatur keseimbangan asam-basa dalam tubuh. Protein dalam tubuh manusia, terutama dalam sel jaringan, bertindak sebagai bahan membran sel, dapat membentuk jaringan pengikat misalnya kolagen dan elastin, serta membentuk protein yang inert seperti rambut 
dan kuku. Disamping itu protein yang bekerja sebagai enzim, bertindak sebagai plasma (albumin), membentuk antibodi, membentuk komplek dengan molekul lain, serta dapat bertindak sebagai bagian sel yang bergerak.

\section{Kadar Lemak}

Penetapan kadar lemak pada Jonjot buah labu kuning tersebut dengan metode soxhlet ini dilakukan dengan cara mengeluarkan lemak dari sampel dengan pelarut petroleum eter. Setelah diekstraksi, maka pelarut diuapkan dalam wadah pada suhu $100{ }^{\circ} \mathrm{C}$ kemudian ditimbang sampai berat konstan. Berat residu dinyatakan sebagai berat lemak. Hasil pengukuran yang ditampilkan pada Tabel 1, diperoleh kadar lemak terdapat pada jonjot sebesar 5,15\%, dibandingkan dengan data penelitian sebelumnya dimana kadar lemak tepung labu kuning sebesar 1,34\% [7]. Hal ini dapat disimpulkan bahwa kadar lemak pada jonjot lebih tinggi dibandingkan tepung labu kuning.

\section{Kadar Serat}

Berdasarkan data hasil pengamatan pada penentuan kadar serat kasar dapat diketahui bahwa kadar serat untuk jonjot buah labu kuning sebesar 1,27\%, dibandingkan dengan data yang diungkapkan oleh Kamsiati (2010), dimana kadar serat tepung labu kuning sebesar 2,90\% [7]. Kadar serat hasil penelitian, lebih kecil dibandingkan dengan serat buah labu kuning hasil penelitian sebelumnya.

Serat kasar terdiri dari selulosa dengan sedikit lignin dan pentosan. Serat merupakan komponen bagi jaringan tanaman yang tahan terhadap proses hidrolisis terhadap enzim dalam lambung dan usus kecil. Serat adalah suatu karbohidrat kompleks di dalam bahan pangan yang tidak dapat dicerna oleh enzimenzim pencernaan manusia, sehingga dapat mencapai usus besar dan dicerna oleh bakteri probiotik. Hal ini menjadikan serat bersifat prebiotik. Konsumsi serat yang cukup setiap harinya dapat mengurangi resiko terkena kanker kolon karena mempersingkat waktu transit makanan. Serat juga menjaga kesehatan mikroflora usus, mencegah hipertensi dan penyakit batu empedu, serta mencegah obesitas.

\section{Kadar Karbohidrat}

Karbohidrat merupakan sumber kalori utama bagi manusia. Kadar karbohidrat yang terdeteksi pada jonjot buah labu kuning 73,38 $\%$. Penelitian sebelumnya menunjukkan kadar karbohidrat tepung labu kuning sebesar 77,65 \% dan $78,77 \%$ [7, 8]. Hal ini menunjukkan karbohidrat pada jonjot labu kuning lebih rendah $\pm 4-5 \%$.

\section{Kadar air}

Kadar air juga salah satu karakteristik yang sangat penting pada bahan pangan, karena air dapat mempengaruhi penampakan, tekstur, dan citarasa pada bahan pangan. Hasil pengujian diperoleh kadar air pada jonjot 14,68 $\%$, dibandingkan dengan kadar air tepung labu kuning menurut Widowati et al., 2001 yakni $11,14 \%$. Perbandingan tersebut di atas disimpulkan kadar air pada tepung jonjot buah labu kuning lebih rendah dari kadar air dalam penelitian sebelumnya. Kadar air dalam bahan pangan ikut menentukan kesegaran dan daya awet bahan pangan tersebut, kadar air yang tinggi mengakibatkan mudahnya bakteri, kapang, dan khamir untuk berkembang biak, sehingga akan terjadi perubahan pada bahan pangan.

\section{Kadar Abu}

Kadar abu mengacu pada residu inorganik yang tersisa setelah oksidasi sempurna dari komponen organik bahan pangan. Nilai kadar abu hasil analisis pada jonjot buah labu kuning sebesar 4,45\%, dibandingkan dengan kadar abu tepung labu kuning menurut Widowati (2001) yakni 5,89\% [8]. Perbandingan tersebut di atas disimpulkan kadar abu pada tepung daging buah labuh kuning lebih rendah dari kadar abu dalam penelitian sebelumnya.

\section{Kesimpulan}

Hasil penelitian menunjukkan bahwa tepung jonjot buah labu kuning memiliki kadar protein $1,09 \%$, lemak $5,15 \%$, serat $1,27 \%$, karbohidrat $73.38 \%$, air $14,68 \%$ dan Abu 4,45 $\%$. Hasil penelitian dapat disimpulkan bahwa tepung jonjot buah labuh kuning dapat dijadikan sebagai bahan fortifikasi pangan untuk meningkatkan nilai gizi. 


\section{Daftar Pustaka}

1. Hendrasty, H. H. K., Teknologi Pengolahan Pangan: Tepung Labu Kuning. Kanisius: 2003.

2. Astawan, M., Labu kuning penawar racun dan cacing pita yang kaya antioksidan. IPB Bogor: 2004.

3. Gumolung, D., Analisis beta karoten dari ekstrak jonjot buah labu kuning (Cucurbita moschata). Fullerene Journal of Chemistry 2017, 2, (2), 69-71.

4. Gumolung, D., Analisis kandungan total fenolik pada jonjot buah labu kuning (cucurbita moschata). Fullerene Journal of Chemistry 2018, 3, (1), 1-4.

5. Sudarmaji, S.; Haryono, B.; Suhardi, Prosedur analisa untuk bahan makanan dan pertanian. Liberty: 1984.

6. Indonesia, S. N., Indonesia 01-2891-1992. Uji makanan dan minuman. Badan Standardisasi Nasional 1992.

7. Kamsiati, E., Labu Kuning untuk Bahan Fortifikasi Vitamin A. In Badan Penelitian Pengengembangan Pertanian Kalimantan Tengah, KalTeng, B., Ed. Badan Penelitian Pengengembangan Pertanian Kalimantan Tengah: Kalimantan Tengah, 2010.

8. Widowati, S.; Damardjati, D. S., Menggali Sumberdaya Pangan Lokal dalam Rangka Ketahanan Pangan. Majalah PANGAN no 2001, 36 . 